\title{
Towards more powerful learning environments through combining the perspectives of designers, teachers, and students.
}

Citation for published version (APA):

Brand-Gruwel, S., Van Merriënboer, J., \& Könings, K. D. (2005). Towards more powerful learning environments through combining the perspectives of designers, teachers, and students. British Journal of Educational Psychology, 75(4), 645-660. https://doi.org/10.1348/000709905X43616

DOI:

10.1348/000709905X43616

Document status and date:

Published: 01/12/2005

Document Version:

Peer reviewed version

Please check the document version of this publication:

- A submitted manuscript is the version of the article upon submission and before peer-review. There can be important differences between the submitted version and the official published version of record. People interested in the research are advised to contact the author for the final version of the publication, or visit the DOI to the publisher's website.

- The final author version and the galley proof are versions of the publication after peer review.

- The final published version features the final layout of the paper including the volume, issue and page numbers.

Link to publication

\section{General rights}

Copyright and moral rights for the publications made accessible in the public portal are retained by the authors and/or other copyright owners and it is a condition of accessing publications that users recognise and abide by the legal requirements associated with these rights.

- Users may download and print one copy of any publication from the public portal for the purpose of private study or research.

- You may not further distribute the material or use it for any profit-making activity or commercial gain

- You may freely distribute the URL identifying the publication in the public portal.

If the publication is distributed under the terms of Article 25fa of the Dutch Copyright Act, indicated by the "Taverne" license above, please follow below link for the End User Agreement:

https://www.ou.nl/taverne-agreement

Take down policy

If you believe that this document breaches copyright please contact us at:

pure-support@ou.nl

providing details and we will investigate your claim.

Downloaded from https://research.ou.nl/ on date: 26 Apr. 2023 


\section{Towards more powerful learning environments through combining the perspectives of designers, teachers, and students}

Karen, D. Könings, Saskia Brand-Gruwel and Jeroen. J.G. Van Merriënboer Educational Technology Expertise Center, Open University of the Netherlands

In order to reach the main aims of modern education, powerful learning environments are designed. The characteristics of the design of PLEs are expected to have positive effects on student learning. Additionally, teachers' conceptions of learning and teaching do influence the implementation of a PLE. Moreover, students’ perceptions of a learning environment affect their subsequent learning behaviour and the quality of the learning outcomes. The different perspectives of educational designers, teachers, and students are summarized in the Combination-of-perspectives (COOP) model. Combining these perspectives by mutual exchange of conceptions and perceptions is expected to have positive effects on the power of PLEs.

British Journal of Educational Psychology, 75, 645-660.

http://www.bps.org.uk/publications/journals/bjep/bjep_home.cfm (c) 2005 BPS. 